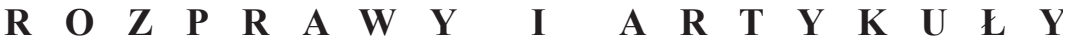

Prawo Kanoniczne 57 (2014) $\mathrm{nr} 4$

KS. GINTER DZIERŻON

Wydział Prawa Kanonicznego

Uniwersytetu Kardynała Stefana Wyszyńskiego w Warszawie

\section{FUNKCJONOWANIE PRAWNEJ INSTYTUCJI LASKI W SYSTEMIE KANONICZNYM}

Treść: Wstęp. - 1. Łaska i jej natura. - 2. Racje funkcjonowania instytucji łaski. - 3. Reskrypt instrumentem prawnym udzielenia łaski. - 4. Udzielanie łaski. Zakończenie.

\section{Wstęp}

Rzeczywistość Kościoła jest wielowymiarowym misterium wiary¹. W refleksji nad tym fenomenem nie można abstrahować m. in. od jego wymiaru pneumatologicznego oraz prawnego. Duch św. bowiem, jak stwierdził Cz. Bartnik, „stanowi szczególny tajemniczy czynnik przechodniości między światem stworzonym a zbawieniem"2. Sobór Watykański II w swym namyśle nad instytucją Kościoła podkreślił z całym naciskiem, że jest On sakramentem zbawienia (KK 48). Zdaniem A. Cattaneo, w tym doktrynalnym stwierdzeniu wyartykułowano jego aspekt funkcjonalny wyrażający się w prawdzie, że Kościół jest narzędziem zbawienia ${ }^{3}$; jest miejscem uobecniania Boga udzielającego się człowiekowi ${ }^{4}$. To On mocą Ducha św. obdarza człowieka swoją łaską. Wspólnota Kościoła jest rzeczywistością działania Bożej łaski. Ta

1 Zob. Cz. Bartnik, Kościół Jezusa Chrystusa, Wrocław 1982, s. 7.

2 Tamże, s. 180.

3 Por. A. Cattaneo, Fondamenti ecclesiologici del diritto canonico, Venezia 2011, s. 88 .

${ }^{4}$ Por. R. Sobański, Kościót - prawo-zbawienie, Katowice 1979, s. 155. 
teologiczna prawda znalazła odzwierciedlenie w treści kilku kanonów Kodeksu 1983 r. (kan. 387, 575, 961 KPK)5.

Należy jednak zauważyć, że w systemie kanonicznym, oprócz fenomenu łaski w znaczeniu teologicznym występuje także instytucja łaski o charakterze prawnym. Stąd też w kanonistyce rozróżnia się pomiędzy pojęciem łaski jako kategorią nadprzyrodzoną oraz pojęciem łaski jako kategorią prawną ${ }^{6}$. Jej jurydyczna natura, racje jej funkcjonowania, instrumenty jej udzielania staną się przedmiotem zainteresowania w tym artykule.

\section{Laska i jej natura}

W obowiązującym Kodeksie z 1983 r. prawodawca nie zawarł definicji legalnej łaski. Podczas prac nad rewizją Kodeksu z 1917 r. zamierzano zdefiniować tę kategorię; odstąpiono jednak od tego zamiaru przekonując, że jest to niemożliwe ze względu na wielość form łaski funkcjonujących w kanonicznym porządku prawnym ${ }^{7}$. Ustawodawca pozostawił zatem doktrynie zdefiniowanie tego pojęcia. E. Labandeira przez łaskę rozumiał to, co nie należy się ze sprawiedliwości; to co wynika z korzyści ${ }^{8}$. Podobnie P. Pavenello określił łaskę jako korzyść, którą otrzymuje wierny, czy to w wyniku poszerzenia sfery swoich praw podmiotowych, czy też w następstwie autoryzacji specjalnego sposobu korzystania z nich ${ }^{9}$. Według zaś U. Rohde, idzie o sytuacje

5 Por. U. Rhode, Gracia (acto administrativo), w: Diccionario general de Derecho Canónico, red. J. Otaduy, A. Viana, J. Sedano, t. 4, Pamplona 2012, s. 237.

${ }^{6}$ Por. J. CAnosa, La concessione di grazie attraverso $i$ rescritti, Ius Ecclesiae 6(1994), s. 241.

7 Por. Pontificia Commissio Codici Iuris Canonici Recognoscendo, Ex actis Commisionis, De actis administrativis, Communicationes 17(1985), s. 46. Prowadzone dyskusje w tej sprawie miały następujący przebieg: „Consultor qui supra petit, si possibile est, ut detur gratiae definitio. Secretarius Adiunctus respondet quod multe sunt species gratiarum, ita ferre impossibile sit definitionem conficere".

8 Por. E. Labandeira, Trattato di diritto amministrativo canonico, Milano 1994, s. 325: „Per grazia s'intende ciò che non è di giustizia, ossia, ciò che non è dovuto ad aequalitatem, ma per convenienza o liberalità".

9 Por. P. Pavenello, La concessione di grazie: aspettative e attese, w: Discrezionalità e descernimento nel governo della Chiesa, red. J. Arrieta, Venezia 2008, s. 179: „Il 
skuteczne prawnie faworyzujące adresata ${ }^{10}$. W następstwie bowiem pozytywnej decyzji władzy kościelnej nabywa on pewne uprawnienie (uprawnienia), które ze sprawiedliwości mu nie przysługują ${ }^{11}$. Trzeba też dodać, iż udzielenie łaski może generować korzystną sytuację prawną adresata tak w sensie aktywnym, jak i pasywnym. Obdarzony nią bowiem może coś podjąć lub też może czegoś zaniechać12.

\section{Racje funkcjonowania instytucji laski}

Występowanie instytucji łaski w systemie kanonicznym w literaturze thumaczy się zarówno racjami teologicznych, jak i prawnymi.

Podejmując pierwszy wątek kanoniści zwracają uwagę, że na kodyfikację Kodeksu z 1983 r. oddziaływała w dużej mierze doktryna Soboru Watykańskiego II, a w sposób szczególny jej wymiar eklezjo$\operatorname{logiczny}{ }^{13}$. Eklezjologia soborowa wpłynęła znacząco na pojmowanie instytucji łaski funkcjonującej w Kościele.

Według L. Wächtera, pomimo tego, że Kodeks nie jest traktatem teologiczno - eklezjologicznym, to jednak wiele regulacji w nim występujących znajduje umocowanie w pryncypiach teologiczno - eklezjologicznych nauki soborowej ${ }^{14}$. Komentatorzy nawiązując do treści zawartej w soborowym „Dekrecie o formacji kapłańskie” (DFK 16)

concetto di grazia contiene il riferimento ad un qualche vantaggio che il fedele riceve, sia nel senso di un allargamento della sfera dei propri diritti soggettivi (è il caso del privilegio e della dispensa), sia nel senso di una autorizazione ad una particolare modalità di esercizio di essi (è il caso della licenza)".

${ }^{10}$ U. RHode, Gracia (acto administrativo), s. 238.

${ }^{11}$ Por. Pontificia Commissio Codici Iuris Canonici Recognoscendo, Coetus studii „De personis physicis et iuridicis”. Sessio XII (diebus 22 - 26 octobis a. 1973 habita), Communicationes 22(1990), s. 304; J. CANOSA, Il rescritto come atto amministrativo nel Diritto Canonico, Milano 2003, s. 217; J. Miras, J. Canosa, E. Baura, Compendio de derecho administrativo canónico, Pamplona 2001, s. 233.

${ }^{12}$ J. Miras, J. Canosa, E. Baura, Compendio..., s. 233.

${ }^{13}$ Por. L. WÄCHTER, Gesetz im kanonischen Recht. Eine rechtssprachliche und systematisch - normative Untersuchung zu Grundproblemen der Erfassung des Gesetzes im katholischen Kirchenrecht, St. Ottilien 1989, s. 242; P. GHERII, Lezioni di Teologia del Diritto, Roma 2004, s. 263-272.

${ }^{14}$ L. WÄCHTER, Gesetz..., s. 245. 
podkreślają, że znaczenie łaski w kanonicznym porządku prawnym wyraża się m. in. w tym, że jest ona komponentem integrującym prawo kościelne. W przeciwieństwie do prawa świeckiego, w prawie kościelnym łaska nie jest kategorią wyjątkową, lecz fenomenem wynikającym z natury Kościoła, który jest sakramentem zbawienia ${ }^{15}$. Jak zauważył J. Canosa, wierni mają prawo nie tylko do takich środków zbawienia jak sakramenty, czy Słowo Boże, lecz mają także prawo do wsparcia pastoralnego ${ }^{16}$. Sprawowanie władzy rządzenia w Kościele domaga się więc nie tylko operowania instrumentami gwarantującymi realizację zasady sprawiedliwości, ale domaga się również dysponowania instrumentami, których wykorzystanie zmierza do doskonalenia sprawiedliwości legalnej ${ }^{17}$; doktrynalnie, idzie o urzeczywistnienie sprawiedliwości bardziej doskonałej ${ }^{18}$. Rozwijając ten wątek hiszpański kanonista podkreślił, że Kościół będąc wspólnotą łaski posiada środki uświęcania służące osiągnięciu celu pryncypialnego jakim jest zbawienia człowieka, nazywane też w literaturze instrumentami Bożego miłosierdzia ${ }^{19}$. Nawiązując do tej myśli P. Pavenello skonstatował, iż ze względu na to, że zbawienie nie jest zasłużone przez człowieka, dlatego też darmowe (gratuiti) są środki prowadzące do tego celu ${ }^{20}$.

Jak już nadmieniono, w doktrynie mówi się nie tylko o racjach teologicznych funkcjonowania instytucji łaski w Kościele, ale wskazuje się także na racje prawne. Jako główne powody z jednej strony wymienia się niemożliwość przewidzenia przez prawodawcę wszystkich sytuacji w jakich może znaleźć się jednostka w systemie, z drugiej zaś

${ }^{15}$ J. Miras, J. Canosa, E. Baura, Compendio..., s. 224-225.

${ }^{16} \mathrm{~J}$. CANOSA, Il rescritto..., s. 225. Autor ten stwierdził: „È proprio in questo senso, che tiene conto del piano di salvezza previsto da Gesù, che si può affermare che i fedeli hanno diritto ai mezzi di salvezza: non soltanto ai sacramenti e alla parola, ma anche alla mediazione del geverno pastorale".

${ }^{17}$ J. Canosa, Il rescritto..., s. 225; J. Miras, J. Canosa, E. Baura, Compendio..., s. 234 .

${ }^{18}$ Por. G. Colombo, Sapiens aequitas. L'equità nella riflesssione canonistica tra i due Codici, Roma 2003, s. 357.

${ }^{19}$ J. CANosa, La concessione di grazie..., s. 239-240.

${ }^{20}$ P. Pavenello, La concessione di grazie..., s. 181. 
wskazuje się na harmonizację dobra wspólnego z dobrem wiernego w konkretnych uwarunkowaniach ${ }^{21}$.

Jednym z celów wprowadzenia ustawy w życie jest organizacja społeczna systemu kanonicznego ${ }^{22}$; idzie o regulację życia społecznego wspólnoty $\mathrm{w}$ jej relacjach interpersonalnych ${ }^{23}$. W tym kontekście autorzy „Compendio de derecho administrativo canónico” trafnie spostrzegli, że pomimo racjonalnego charakteru tego aktu prawnego wprowadzenie ustawy nie jest celem samym w sobie, ale środkiem kwalifikowanym w organizacji życia wspólnoty. Nie oznacza to zatem, że w konkretnym przypadku trzeba ją stosować w sposób formalistyczny; wręcz odwrotnie, należy ją aplikować w sposób elastyczny ${ }^{24}$. Realizacji tego założenia służą $\mathrm{m}$. in. akty łaski ${ }^{25}$. Dlatego też w prawie kościelnym ze względu na specyficzne nieprzewidziane ustawą uwarunkowania w których mogą znaleźć się wierni, możliwe jest udzielenie łaski przez kompetentną władzę kościelną ${ }^{26}$.

\section{Reskrypt instrumentem prawnym udzielenia laski}

Mówiąc o instytucji łaski trzeba rozróżnić pomiędzy zawartością aktu łaski, a aktem jako instrumentem udzielania łaski ${ }^{27}$. W systemie kanonicznym instrumentem tym jest reskrypt ${ }^{28}$.

W kan. 59 § $1 \mathrm{KPK}$ postanowiono bowiem, że poprzez tego typu akt administracyjny „,udziela się przywileju, dyspensy lub innej łaski”.

${ }^{21}$ J. Otaduy, Lezioni..., s. 199; J. Miras, J. Canosa, E. Baura, Compendio..., s. 234.

22 J. OtAduY, Lezioni..., s. 29.

${ }^{23}$ Por. V. De Paolis, A. D'Auria, Le norme generali di Diritto Canonico. Commento al Codice di Diritto Canonico, Roma 2008, s. 94.

${ }^{24}$ J. Miras, J. Canosa, E. Baura, Compendio..., s. 235: „Esto no obsta para que, en ciertos casos concretos, resulta compatible con el bien comun y conveniente para el bien de las persona concretas aplicar fexiblmente o no aplicar una norma, o incluso disponer ad casum para una situaciòn determinada".

${ }^{25}$ Por. P. LombardíA, Lecciones de Derecho canónico, Madrid 1984, s. 166.

${ }^{26}$ Por. F. D’Ostilio, Il diritto amministrativo della Chiesa, Città del Vaticano 1996, S. 419.

${ }^{27}$ J. CANosA, La concessione di grazie..., s. 243.

${ }^{28}$ Por. D. Di Felice, L'istituto della grazia nel diritto canonico ed ecclesiastico, Il Diritto Ecclesiatico 106(1995)/I, s. 251. 
Stąd też w doktrynie mówi się, że reskrypty są aktami łaski ${ }^{29}$. Prawda ta została wyrażona wyraźnie w definicji legalnej przywileju zawartej w kan. $76 \S 1$ KPK. W regulacji tej stwierdzono, że przywilej jest łaską udzieloną dla osób fizycznych lub prawnych ${ }^{30}$. Według E. Labandeiry, dyspensa jest jedną z postaci przywileju; jest przywilejem przeciw pra$w^{31}$. Na marginesie należy dodać, iż w doktrynie nie istnieje zgodność poglądów co do tego, czy zezwolenie jest reskryptem. Niejednorodność opinii wynika z faktu, że w kan. 1510 § 2, n. 3 KKKW licencję zaliczono do reskryptów; w kan. 59 KPK natomiast stanowi ona odmienną kategorię 32 .

Jurydyczny zwrot, ,inne łaski” o którym traktuje kan. 59 § 1 KPK występuje też w innych aktach prawnych. Dla przykładu, w art. 118 Konstytucji „Pastor bonus” stwierdzono, że do kompetencji Penitencjarni Apostolskiej należy m. in. udzielenie innych łask ${ }^{33}$.

Według U. Rhode, tylko przywileje i dyspensy są aktami przeciw lub obok prawa; innych łask bowiem udziela się zgodnie z prawem ${ }^{34}$. W systemie kanonicznym funkcjonuje wiele instytucji służących udzieleniu tego typu łaski. W literaturze egzemplarycznie wskazuje się na uważnienie małżeństwa, rozwiązanie małżeństwa ważnie zawartego, lecz niedopełnionego ${ }^{35}$ oraz rekurs hierarchiczny ${ }^{36}$.

\section{Udzielanie laski}

Substancjalnie wydanie reskryptu z jednej strony wiąże się z poszerzeniem sfery prawnej udzielającego, z drugiej zaś służy faworyzowaniu adresata tego aktu ${ }^{37}$.

${ }^{29}$ U. Rhode, Gracia (acto administrativo), s. 238; D. Di Felice, L'istituto della grazia..., s. 251.

${ }^{30}$ U. RHode, Gracia (acto administrativo), s. 238.

${ }^{31}$ Por. E. BAURA, La dispensa canonica della legge, Milano 1997, s. 216-217.

${ }^{32}$ J. CANosa, Il rescritto..., s. 221. E. Labandeira stoi na stanowisku, że zezwolenie nie jest reskryptem. E. LABANDEIRA, Trattato..., s. 324-325.

${ }^{33}$ Por. Joannes Paulus II, Constitutio Pastor bonus - 28.06.1988, 80 (1988), s. 890.

${ }^{34}$ U. Rhode, Gracia (acto administrativo), s. 238.

${ }^{35}$ J. CANOSA, Il rescritto..., s. 221.

${ }^{36}$ D. Di Felice, L'istituto..., s. 250-253.

${ }^{37}$ J. CAnosa, La concessione di grazie..., s. 245. 
W systemie kanonicznym udzielanie łaski pozostaje w ścisłym związku nie tylko z formalnym charakterem reskryptu, ale przede wszystkim z naturą tego $\mathrm{aktu}^{38}$. Zasadnicza racja jego funkcjonowania wiąże się ze wspominaną już naczelną zasadą systemu kanonicznego, jaką jest zbawienie człowieka (kan. $1752 \mathrm{KPK})^{39}$.

W porządku kanonicznym wierny otrzymuje dobro, o które prosi w wyniku decyzji kompetentnej władzy kościelnej. W myśl założeń systemowych, istnieje współzależność pomiędzy udzielaną łaską a formalnym charakterem aktu ${ }^{40}$. Rozwijając ten wątek należy zauważyć, iż działalność administracyjna w Kościele służy dwom celom; z jednej strony wiąże się ona z troską o dobro wspólne, z drugiej zaś z troską o dobro jednostki, jakim jest wierny. Stąd też w procesie formacyjnym decyzji władzy kościelnej niejednokrotnie dochodzi do swoistego napięcia związanego z realizacją tych pryncypiów ${ }^{41}$. Udzielenie łaski bowiem domaga się oceny dyskrecjonalnej; oceny tego, o co się prosi ${ }^{42}$. $\mathrm{W}$ podejmowaniu decyzji bowiem idzie nie tyle o dobro tego, który ją podejmuje, ale o dobro tego, który otrzymuje łaskę ${ }^{43}$.

Władza kościelna udzielająca łaski musi szukać dobra dla wiernego lub grupy wiernych w konkretnej sytuacji w której się znajdują ${ }^{44}$. Dlatego też w doktrynie podkreśla się, iż pozytywne ustosunkowanie do zaistniałej sytuacji powinno nastąpić wyłącznie z powodu słusznej przyczyny ${ }^{45}$. Zdaniem E. Labandeiry, przyczyna o takim parametrze powinna wynikać z motywów sprawiedliwości lub słuszności ${ }^{46}$. Należy przypomnieć, iż prawodawca w kan. 90 § 1 KPK dla udzielenia dyspensy wymaga zaistnienia słusznej i racjonalnej przyczyny. U. Rhode, odnosząc się do instytucji łaski wskazał, iż przyczyna ta powinna być także proporcjonalna ${ }^{47}$.

\footnotetext{
${ }^{38}$ P. PaVenello, La concessione di grazie..., s. 181.

${ }^{39}$ Tamże, s. 182.

${ }^{40}$ J. CANosa, Il rescritto..., s. 227-228.

${ }^{41}$ P. Pavenello, La concessione di grazie.., s. 184.

${ }^{42}$ Tamże, s. 182.

${ }^{43}$ Tamże, s. 183.

${ }^{44}$ Tamże, s. 182-183.

${ }^{45}$ E. Labandeira, Trattato..., s. 325.

${ }^{46}$ Tamże.

${ }^{47}$ U. RHode, Gracia (acto administrativo), s. 238.
} 
Wracając do przerwanego wątku należy zauważyć, iż dyskrecjonalność o której mowa nie oznacza jednak arbitralności. Wykonywanie władzy administracyjnej bowiem nie może pomijać podstawowych zasad porządku prawnego; musi być ono podporządkowane regułom prawnym umożliwiającym wspólnocie weryfikację działań ${ }^{48}$.

We współczesnej kanonistyce problem funkcjonowania instytucji łaski rozważa się również w kontekście fundamentalnych praw wiernych w Kościele ${ }^{49}$. Otóż wskazuje się, iż podejmowanie tego typu decyzji powoduje pewne napięcie ze względu na prawo wszystkich wiernych do równości (kan. 208 KPK). Niektórzy komentatorzy przekonują, że korzyści, które otrzymują wierni obdarowani łaską godzą w pryncypialną równość wszystkich wiernych w Kościele ${ }^{50}$. Takiemu podejściu, przeciwstawiają się m. in. autorzy „Compendio de derecho administrativo canónico" podkreślając, że akty łaski w niczym nie naruszają dobra wspólnego; protegują natomiast podmiot znajdujący się w specyficznych uwarunkowaniach ${ }^{51}$. W opinii U. Rhode, udzielenie łaski wiernemu w sytuacjach szczególnych wpisuje się organicznie w fundamentalne pryncypium kanonicznego porządku prawnego, zgodnie z którym naczelnym prawem jest zbawienie człowieka (kan. $1752 \mathrm{KPK})^{52}$.

\footnotetext{
${ }^{48}$ P. Pavenello, La concessione di grazie..., s. 183; „Discrezionalità però non significa arbitrarietà. L'esercizio della potestà amministrativa, in cui rientra anche la concessione di grazie, non può mai prescindere da un vincolo di ordine, razionalità e certezza: esso non può mai essere lasciato all'libero arbitrio soggettivo dell'autorità, ma deve sottoposto a regule giuridiche che ne permettano la verifica da parte di communità".

${ }^{49}$ J. CAnosa, La concessione di grazie..., s. 238.

${ }^{50}$ M. J. Roca, Comentario al can.76, w: Comentario exegético al Código de Derecho Canónico, red. A. Marzoa, J. Miras, R. Rodríguez - Ocaña, t. 1, Pamplona 1996, S. 651 .

${ }^{51}$ J. Miras, J. Canosa, E. Baura, Compendio..., s. 237: „Es lógico, pues, que el derecho administrativo se ocupe de la regulación de las gracias. A travès de ellas la autoridad procura favorecer a los agraciados ampliando razionablmente sus posibilidades de actuaciòn, en consideraciòn a sus circumstancias y necesidades particulares [...]".

${ }^{52}$ U. Rhode, Gracia (acto administrativo), s. 238: „La posibildad de conceder gracias no está en contradicciòn con la igulalidad de todos los fieles en cuanto a la dignidad y acción - en términos del c. 208 - pero en una inevitable tensión. Dicha posibili-
} 


\section{Zakończenie}

Obecne rozumienie instytucji łaski znacznie różni się od tego, które istniało pod rządami Kodeksu z 1917 r. Wówczas pod wpływem prawa rzymskiego, jej udzielanie wiązano z naturą prywatystyczną (natura privatistica), to znaczy wpisywano ją w relację zachodzącą pomiędzy władzą udzielającą a adresatem aktu. Udzielanie łaski ówcześni komentatorzy porównywali do donacji. Twierdzili oni, iż łaska redukuje prawny stan posiadania (patrimonio giuridico) udzielającego, podobnie jak donacja redukuje ekonomiczny stan posiadania (patrimonio economico) osoby ${ }^{53}$.

Ewolucja spojrzenia na prezentowaną instytucję nastąpiła pod wpływem doktryny Soboru Watykańskiego II. Współczesne bowiem rozumienie tego fenomenu nie ma charakteru reistycznego, ale wypływa z przesłanek teologiczno - personalistycznych. W literaturze przedmiotu podkreśla się, iż współczesny koncept łaski wynika m.in. z przyjętego podczas prac kodyfikacyjnych 6 pryncypium rewizji Kodeksu. W przywołanej zasadzie stanowiono, iż w systemie prawa kościelnego powinny zostać zagwarantowane wszystkie prawa wiernych; zarazem jednak wskazywano, że akty władzy kościelnej stojące na straży realizacji tych praw powinny być pozbawione arbitralności ${ }^{54}$. Wyjaśniając przesłanie ujęte w tym pryncypium H. Pree podkreślił, iż sprawowanie władzy w Kościele powinno mieć charakter służebny ${ }^{55}$.

Jak wykazano, akty łaski protegują jednostkę, która znalazła się w nieprzewidzianych ustawą okolicznościach. Stąd też władza podejmująca działanie w konkretnym przypadku $\mathrm{z}$ jednej strony powinna mieć na uwadze szczególną sytuację w której znalazł się wierny, z dru-

dad presupone que, en casos individulaes, la concesión de una gracia puede facilitar la salvación de las almas - que debe ser siempre la ley suprema de la Iglesia [...]".

${ }^{53}$ P. Pavenello, La concessione di grazie..., s. 180-181.

${ }^{54}$ Por. Pontificia Commissio Codici Iuris Canonici Recognoscendo, Principia quae Codicis Iuris Canonici recognitionem dirigant, Communicationes 2 (1969), s. 82-83.

${ }^{55}$ Por. H. PreE, Esercizio della potestà e diritti dei fedeli, w: I principi per la revisione del Codice di Diritto canonico. La recezione giuridica del Concilio Vaticano II, red. J. Canosa, Milano 2000, s. 309. 
giej zaś strony powinna rozważyć czy podjęta decyzja będzie służyła jego zbawieniu (kan. 1752 KPK).

\section{The functioning of a legal institution of grace in canonical legal system}

The author of the presented article reflected on the issue of a legal institution of grace in canonical legal order. The analyses carried out by the author showed that the approach of the ecclesial legislator evolved. He moved from the reistic understanding of this institution putting the emphasis on its theological-personal dimension. The author proved that according to the conventional assumptions, the acts of grace favour an individual who finds himself in circumstances unexpected in the law. For this reason, ecclesiastical power while taking any action in a particular case should take into account the specificity of the situation the faithful is in but should also consider if the decision made would lead to his salvation (can. 1752 CIC).

SŁowa KLUCZOWE: łaska, system kanoniczny, reskrypt

KEY WORDS: grace, canonical system, rescript, ecclesiastical power 